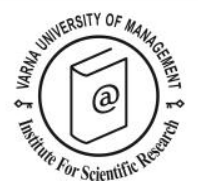

\title{
Does Quality Standards Certification Truly Matter on Operational and Business Performances of Firms?
} Evidence from Resort Hotels

\author{
Feridun Duman ${ }^{1}$, Ozgur Ozer ${ }^{2}$, Mehmet Ali Koseoglu ${ }^{3 *}$, Mehmet Altin ${ }^{4}$ \\ and Fevzi Okumus ${ }^{5}$
}

Received: 11/12/2018 Accepted: 25/02/2019

\footnotetext{
1 School of Tourism and Hospitality Management, Batman University, Batman, Turkey. E-mail: feridun_duman@hotmail.com

2 Faculty of Tourism, Necmettin Erbakan University, Konya, Turkey. E-mail: ozgurozer64@gmail.com

3 School of Hotel and Tourism Management, The Hong Kong Polytechnic University, Kowloon, Hong Kong. Emails: MehmetAli.Koseoglu@polyu.edu.hk; trmaliktr@yahoo.com

4 Rosen College of Hospitality Management, University of Central Florida, Orlando, FL, USA. E-mail: mehmet.altin@ucf.edu

5 Rosen College of Hospitality Management, University of Central Florida, Orlando, FL, USA. E-mail: fevzi.okumus@ucf.edu

* Corresponding author

Coordinating editor: Stanislav Ivanov
}

\section{Abstract}

This study aims to determine the effects of ISO 9001:2015 quality certification on the firm performance. A questionnaire survey was used to collect data from 241 resort hotels in Turkey. The EFA (Exploratory Factor Analysis) and Cronbach alpha were used in order to test the unidimensionality and reliability of the scales. The difference between the ISO 9001 non/certified resort hotels was determined by $t$-test in order to test the hypothesis. As one of the first study focusing on how ISO 9001:2015 quality certification influence organizational and business performances of resort hotels in an emerging economy. The results show a significant relationship between the ISO 9001 quality certification and the operational performance, but not a positive one. However, the study does not show any significant relationship between the ISO 9001 quality certification and business performance. Finally, this study provides theoretical and practical implications with limitations and suggestions for potential future studies.

Keywords: ISO 9001; quality certification; operational and business performance; hotels

Citation: Duman, F., O. Ozer, M. Koseoglu, M. Altin and F. Okumus (2019) Does Quality Standards Certification Truly Matter on Operational and Business Performances of Firms? Evidence from Resort Hotels. European Journal of Tourism Research 23, pp. 142-155

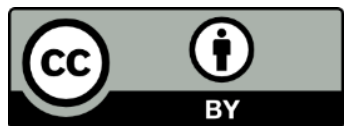

This work is licensed under the Creative Commons Attribution 4.0 International (CC BY 4.0). To view a copy of this license, visit https://creativecommons.org/licenses/by/4.0/ 


\section{Introduction}

One of the major topics investigated in strategic management is why some firms outperform others. There have been many determinants investigated previously to understand reasoning behind high performers (Altin, Koseoglu, Yu, \& Riasi, 2018; Sainaghi, Köseoglu, d'Angella, \& Tehheh, 2019; Sainaghi, 2010; Sainaghi, Phillips, \& Corti, 2013; Sainaghi, Phillips, Baggio, \& Mauri, 2018). One of the topics discussed is the relationship between quality management level and the firm's performance (Samson \& Terziovski, 1999; Flynn, Schroeder \& Sakakibara, 1995; Kaynak, 2003). While some studies examined the quality management and performance relationship by employing survey methods, others utilized secondary data measurement methods such as quality management certifications. There are as many as 60 quality standards certifications that are available for both manufacturing and service firms around the world. These certifications have been used to compete in quality globally, and, in turn, to improve firms' operational and business performance (Aba and Badar, 2013). ISO (International Standardization for Organization) 9001 quality programs, for example, certified over one million companies in 2016 (ISO, 2017). Many firms, in general, opt for ISO 9001 quality management certification to improve quality standards and to maintain these quality standards across their organizations (White et al., 2009).

The ISO 9001 quality management system is easily adopted to many different sectors with varying sizes of firms (Zeng et al., 2007; AlRawahi and Bashir, 2011), however, this quality certification provides a set of principles and procedures leading towards establishing a set of quality standards to be followed by firms and does not guarantee quality assurance. While the notion of being certified does not guarantee a better quality assurance, the purpose of many firms adopting ISO 9001 quality management certification is to establish a superior organizational performance. Adopting ISO 9001 quality certification serves to convey the quality standards to their customers for manufacturing and service firms. For example, Su et al. (2008) state that a quality management system could improve products and reduce costs, and, in turn, generate more satisfaction amongst customers and better organizational performance. There are many studies published with conflicting results regarding whether a quality management certification supports the improvement of both operational and business performance of firms (Alic and Rusjan, 2010; Sampaio et al., 2011). Therefore, this study addresses how adopting a quality management system, such as ISO 9001, could improve operational and business performance of resort hotels in a climate of intense competition.

Turkey is an important destination for many international visitors. However, recent problems associated with multiple wars around the region and Turkish/Russian conflict has created issues within the Turkish hotel sector. Since the competition amongst hotels has become fiercer, performance enhancement is becoming more important to the success of these hotels. Given that quality management system can be an important strategic option, hotels are adopting these systems to enhance performance and gain an edge over their competitors (Trigueros Pina and Sansalvador Sells, 2008). To the best of authors knowledge, there are limited studies on quality management certifications, the effect of ISO 9000 on quality management practices (Rao et al., 1997), the benefits of ISO 9000 (Nield and Kozak, 1999), and the environmental certification on hotel guest ratings (PieroSignes et al., 2014). Thus, there is a recent need in the literature to expand prior work on whether ISO 9001: 2015 quality certification affects the organizational performance in service firms. Therefore, this study specifically attempts to compare ISO 9001: 2015 certified hotels to non-certified hotels focusing on performance measures from both operational and business perspectives in the Turkish hotel sector.

This paper first discusses the current literature on ISO 9001:2015 quality management system and its effects on the firms' performances. Following this, the research hypotheses are formulated. Secondly, research methodology is explained including questionnaire development, sampling and data analysis. Thirdly, results of the study are presented and the findings are 
discussed. Finally, conclusions are presented along with study limitations and future studies opportunities.

\section{Literature review}

In order to earn a quality management certification, companies must commit to important responsibilities to change or adapt their current organizational structure and their processes and management philosophy. Many of these companies are under the assumption that if they have a quality management certification, they will become more attractive for guests, which may then increase the demand on their property. Therefore, receiving these certifications should help them to increase their performance. This assumption opens up a great opportunity for researchers to answer if and how a quality management certification impacts companies' performance. Currently, many studies (Aba et al., 2016; Al Refaie et al., 2012; Chatzoglou et al., 2015; Chow-Chua, et al., 2003; Feng et al., 2008; Jang and Lin, 2008; Naser et al., 2004; Nicolau and Sellers, 2002; Mokthar and Muda, 2012; Psomas and Kafetzopoulus, 2014; Wu and Chen, 2011) indicated that having quality management certification, particularly ISO 9000, positively impacts business performance.

However, contrasting studies (Aarts and Vos, 2001; Beirao and Cabral, 2002; Dimara et al., 2004; Dunu and Ayokanmbi, 2008; Haversjo, 2000; Heras et al., 2002; Heras-Saizarbitoria et al., 2015; Ilkay and Aslan, 2012; Islam et al., 2016; Kusumah and Fabianto 2016; Lima et al., 2000; Martinez-Costa and Martinez-Lorente, 2003; Naveh and Marcus, 2005; Ochieng et al., 2015; Sampaio et al., 2011) demonstrated that there is no economic effect of having a quality management certification such as ISO 9000 on business performance. In this respect, Tsekouras et al., (2002) and Wayhan et al., (2002) suggested that adopting the ISO 9000 quality system in the short-term might not reveal the expected return on performance. In addition to both the supporting and contradictory literature produced by the ISO 9001 quality system on performance studies discussed above, other researchers demonstrated that some certified firms are generally more profitable than those that are not, and these researchers suggested that the firms in question were more profitable before their quality certification (Haversjo, 2000; Heras et al., 2002; Naveh and Marcus, 2005). This difference in profitability of the certified firms might suggest that these types of firms have a focus towards being certified rather than implementing the ISO 9001 quality system (Chow-Chua et al., 2003). Furthermore, the discrepancies in the performance findings of ISO 9001 quality system studies indicated that the firms adopting this certification are more homogenous and better internalize the quality standards. To summarize, the different levels of internalization in implementing the quality certification affect the financial and nonfinancial performances of the firms.

In the literature there are a number of studies developing performance models for firms, including financial and non-financial performances' indicators (see Altin et al., 2018). For hotels Sainaghi (2010) suggested a performance model including i) qualitative clients' indicators; ii) operational performance; iii) business (or financial performance), iv) organizational (or institutional) performance. Qualitative clients' indicators measure the satisfaction of clients and more generally the image. The characteristics of this first group is their link with subjective measures related to the demand approach (client). Operational performance includes indicators related to the operating activity but excluding the economic margins. These metrics are objective, and they include occupancy, revenues (sales), market share. They are based on revenues (variously operationalized) or on quantitative determinants of sales (as occupancy). Business or financial indicators are based on economic margins and therefore they include not only revenues (or sales) and the determinants of revenues (as the second group), but they include also costs. Finally, organizational or institutional performance focuses on different stakeholders. For our study we condense these groups as two groups as seen Table 1 since some measures may generate overlaps among the groups and some measures may not measure sufficiently and not identified clearly by managers. 
Table 1. Literature pertinent to ISO 9001 and performance measures

\begin{tabular}{|c|c|c|}
\hline Performance measures & Performance variables & Supporting literature \\
\hline Operational performance & $\begin{array}{l}\text { Employee satisfaction } \\
\text { Low cost in production } \\
\text { Customer satisfaction }\end{array}$ & $\begin{array}{l}\text { Feng et al., (2008); Jang and Lin (2008); Wu } \\
\text { and Chen (2011); Al-Refaie et al., (2012); } \\
\text { Psomas and Kafetzopoulus (2012); Chatzoglou } \\
\text { et al., (2015). }\end{array}$ \\
\hline Business performance & $\begin{array}{l}\text { Corporate image } \\
\text { Market share } \\
\text { Occupancy } \\
\text { Revenues (Sales) } \\
\text { Profitability }\end{array}$ & $\begin{array}{l}\text { Nicolau and Sellers (2002); Chow-Chua et al., } \\
\text { (2003); Naser et al., (2004); Feng et al., } \\
\text { (2008); Wu and Chen (2011); Al-Refaie et al., } \\
\text { (2012); Mokthar and Muda (2012); Psomas et } \\
\text { al., (2012); Chatzoglou et al., (2015); Aba et } \\
\text { al., (2016). }\end{array}$ \\
\hline
\end{tabular}

Business performance holistically measures market and financial performance of firms (see Table 1). Specifically, market performance measures the competence of companies to increase their share on domestic and overseas markets (White et al., 2009). Within this context, ISO 9001 would give an essential benefit for the companies to grow and expand domestically and internationally. In the quality management literature, particularly the measures of market performance, the company image and market share have received much attention as to show the relationship between quality management and market performance (Gonzalez-Benito, 2005; Skrinjar et al., 2008; Agus and Hajinoor, 2012). However, not many empirical studies have been conducted on the specific relationship between ISO 9001 quality system and market performance (Jang and Lin, 2008; Psomas et al., 2012; Chatzoglou et al., 2015). As for the financial perspective of the performance, revenues (sales) and profitability are the main proxies measured in order to determine the financial performance in the manufacturing and service businesses. With this perspective, adopting a quality management system is utilized with the intention to outperform their competitors by gaining a better financial outcome for their businesses. Therefore, the adoption of a quality management system such as ISO 9001 should be evaluated whether it indicates a positive effect on the revenues (sales) and profitability as the proxies of the resort hotels' financial performance. Findings in the current empirical literature are not consistent and are even contradictory when identifying a positive relationship between ISO 9001 quality management system and financial performance
(Feng et al., 2008; Lo et al., 2014; Kusumah and Fabianto, 2016). These contradictory findings show that there is a need for further research on the effects of the ISO 9001 quality system on the financial performance. However, more specifically, Nava Carballido and RivasTovar (2008), Rubio-Andrada et al. (2011), and Tarí et al. (2009) showed that implementing quality programs improves hotels' performance. Therefore, Hypothesis $(H) 1$ is proposed:

\section{H1: ISO 9001 certified resort hotels outperform the non-certified resort hotels in terms of business performance.}

Although the literature has intensely focused on business or firm performance, studies related to how specific quality management systems influence operational performance from a holistic perspective are rare. Operational performance, including employee satisfaction, low cost in production, customer satisfaction, and customer loyalty (see Table 1) in quality management systems are key subjects investigated in the empirical studies emphasizing a cause-effect relationship between ISO 9001 and the internal processes of the manufacturing and service companies, in which the operational performance is considered to measure the effectiveness of the quality management systems such as ISO 9001, EFQM, MBNQA, the Malcolm Baldrige, Six Sigma etc. ISO 9001 quality standards system requires all the procedures of a firm's processes to be systematically organized and implemented. All of the outcomes through this quality standards system are controlled, and variations caused in production by the processes of receiving supplies and the 
complaints of the customers are reduced in order to achieve the organizational goals within a given timeframe. Various studies showed the application of ISO 9001 quality standards directly and positively affected the operational performances in manufacturing and service companies (Jang and Lin, 2008; Psomas et al., 2012). This stipulates a business situation in which all businesses are required to stay close to their customers in order to determine their customers' constantly changing wants and needs over time. Although the relationship between the quality management practices, customer satisfaction, and loyalty are very wellresearched in the total quality management literature (e.g. Ahire and O'Saughnessy, 1998; Dow et al., 1999; Samson and Terziovski, 1999; Rahman and Bullock, 2005; Feng et al., 2006; Lakhal, 2009), very few studies looked into the relationship between the ISO 9001 quality system and customer satisfaction and loyalty (Al-Refaie et al., 2012; Wu and Chen, 2011; Psomas et al., 2012; Chatzoglou et al. , 2015). More specifically for the hotel industry, while Claver et al. (2006), Minazzi (2006), Tarí et al. (2010), and Tarí et al. (2014) found that implementation of quality systems (ISO 9001) increases customer satisfaction, AlonsoAlmeida \& Rodríguez-Antón (2011) highlighted that customer satisfaction is not increased with the implementation of quality systems (ISO 9001). Also, Tarí et al. (2010) demonstrated that quality systems help hotels improve their hotel's image and service quality. Therefore, $\mathrm{H} 2$ is proposed:

H2: ISO 9001 certified resort hotels outperform the non-certified resort hotels in terms of operational performance.

\section{Methodology}

\section{Survey instruments and measures}

The study questionnaire was developed by specifically reviewing the measures of the empirical ISO 9001 performance dimensions in the literature. After the literature review, the performance dimensions for the study were holistically considered in order to measure the operational and business performances of the resort hotels (see Table 1). Before the questionnaire was sent out to the resort hotels, it was examined by the authors, other academics, and was pilot tested using 15 ISO
9001 registered resort hotel managers (Tabachnick and Fidell, 2007).

The questionnaire consisted of two sections. The first section required information about the resort hotels' backgrounds. In the second section, the questions were asked to the ISO 9001 certified and non-certified resort hotel companies about their operational and business performances. In this section, the performance dimensions were constructed through the specific literature review as follows: operational performance (Feng et al., 2008; Jang and Lin, 2008; Wu and Chen, 2011; AlRefaie et al., 2012; Psomas et al., 2012; Chatzoglou et al., 2015) and business performance (Nicolau and Sellers, 2002; ChowChua et al., 2003; Naser et al., 2004; Feng et al., 2008; Wu and Chen, 2011; Al-Refaie et al., 2012; Mokthar and Muda, 2012; Psomas et al., 2012; Chatzoglou et al., 2015; Aba et al., 2016). A five-point Likert scale with items comprising the performance dimensions was presented to the resort hotel general managers, where 1 represented "strongly disagree" and 5 represented "strongly agree".

\section{Data Collection}

The population of this study consisted of four and five-star hotels located in Turkey since these hotels as large size companies may consider adopting quality systems more seriously and proactively than small and medium size hotels. The study employed a questionnaire technique to measure both operational and business performance of these resort hotels, and their certification status in Turkey. A list of hotels and their email addresses were obtained from the Turkish Ministry of Culture and Tourism. All of the hotels in Turkey are required to register with the Turkish Ministry of Culture and Tourism (2016), however, they are not required to report their certification status. The targeted population list (1142 hotels) for the study consisting of four (657) and five (485) star hotels was obtained. It was not possible to find the exact number of the four and five-star resort hotels that were certified with ISO 9001. Therefore, the main issue was access to certified resort hotels. This was managed by contacting each sample hotel to find out whether they had the ISO: 2015 quality 
management system. With this approach, the research sample made sure that the certified and non-certified resort hotel managers equally filled up the questionnaires. Among 1142 hotels, 241 resort hotels (57 four stars and 184 five stars) participated in this study. Of these resort hotel companies, the ISO 9001 certified resort hotels were 120 and the remaining 121 were the non-certified resort hotel companies. The questionnaire survey took place from June 2017 to October 2017. Initially, 142 questionnaires were completed after one month, which was enough time to wait for the returns of the questionnaires (Cooper and Schilinder, 1998). The rest of the 104 questionnaires were obtained later by contacting the resort hotel managers and reminding them to fill out the questionnaires that had been sent to them by email one month earlier. Five questionnaires were omitted due to missing information, and 241 questionnaires were included to be analyzed for this study.

\section{Data analysis}

The EFA (Exploratory Factor Analysis) and Cronbach alpha were employed in order to test the unidimensionality and reliability of the scales for performance measures. EFA helps to extract the best possible latent factors to describe the correlations of performance measuring variables (Pallant, 2007). Therefore, the most common technique to apply EFA in order to extract the latent factors of the study's data was the principal components analysis. Then, the orthogonal varimax rotation method was used for the factor rotation for the study (Tabachnick and Fidell, 2007). The outcome of the EFA provided two distinctive measures, business and operational performances, that could be further tested. The study employed a $t$-test in order to compare certified and noncertified resort hotels' operational and business performances in the study.

\section{Results}

The profiles of the sample hotels

The studied resort hotels were categorized according to their size (number of bedrooms), quality rating (number of stars), and the affiliation of the hotels (franchising, management contracts and independent hotels). This information is summarized separately under the headings of ISO 9001 certified and non-ISO 9001 certified resort hotels at Table 2.

The first characteristic of the resort hotels studied was their size, which is presented according to the number of rooms. The size of the resort hotels is categorized into three groups: "Up to 200 rooms", "Between 201 and 400 rooms", and "401 and over rooms". By examining the sample hotels, one will see that the resort hotels with the ISO 9001 certification ("401 and over rooms", 40\%) are more than the non-certified ones (23\%). While the size of "between 201 and 400 rooms" is well distributed amongst themselves, the ISO 9001 certified hotels with up to 200 rooms $(26.6 \%)$ are less than the non-ISO 9001 certified ones $(41.3 \%)$.

For quality ratings, the Turkish Ministry of Culture and Tourism hotel quality qualification was chosen, and only four-star resort hotels $(30 \%)$ and five-star resort hotels $(70 \%)$ were selected for this study. These resort hotels with the ISO 9001 certification and non-ISO 9001 certification are distributed in proportion so that the results of the study are to be statistically significant. By looking at Table 2 below, 18.3\% of four star and $81.7 \%$ of five-star resort hotels are certified. On the other hand, $28.9 \%$ of four star and $71.1 \%$ of five- star resort hotels are non-certified respectively. Therefore, the ISO 9001 certified and non-certified resort hotels are almost equally distributed.

The last characteristic of the study sample was the affiliation (franchising, management contracts and independents) of the resort hotels. Both independent ISO 9001 certified and independent non-ISO 9001 certified hotels comprise $62 \%$ of the sample. The categories of franchising $(18.3 \%$ certified and $10.8 \%$ noncertified hotels respectively) and management contracts $(20 \%$ certified and $26.4 \%$ noncertified hotels respectively) are well-distributed across the sample studied.

\section{Exploratory Factor Analysis for Performance Measures}

Having examined the profiles of the sample, this study used the identified performance factors based on the ISO 9001 quality certification and performance literature mentio- 
Does Quality Standards Certification Truly Matter on Operational and Business Performances of Firms?

Evidence from Resort Hotels.

Table 2. Profiles of Sample Resort Hotels $(n=241)$

\begin{tabular}{|c|c|c|c|c|c|c|}
\hline Hotel Profiles & $\begin{array}{l}\text { ISO } \\
\text { certified } \\
\left(n_{1}=120\right)\end{array}$ & $\begin{array}{r}9001: 2015 \\
\text { hotels }\end{array}$ & $\begin{array}{l}\text { Non-ISO } \\
\text { certified } \\
\left(\mathrm{n}_{2}=121\right)\end{array}$ & $\begin{array}{r}9001: 2015 \\
\text { hotels }\end{array}$ & $\begin{array}{l}\text { Total } \\
(\mathrm{n}=241)\end{array}$ & \\
\hline Number of Rooms & $f$ & $\%$ & $f$ & $\%$ & $f$ & $\%$ \\
\hline Up to 200 & 32 & 26.6 & 50 & 41.3 & 82 & 34.0 \\
\hline Between 201 and 400 & 40 & 33.4 & 43 & 35.5 & 83 & 34.4 \\
\hline 401 and over & 48 & 40 & 28 & 23.2 & 76 & 31.5 \\
\hline Total & 120 & 100 & 121 & 100 & 241 & 100.0 \\
\hline Staring & f & $\%$ & f & $\%$ & & \\
\hline 4 star & 22 & 18.3 & 35 & 28.9 & 57 & 23.7 \\
\hline 5 star & 98 & 81.7 & 86 & 71.1 & 184 & 76.3 \\
\hline Total & 120 & 100 & 121 & 100 & 241 & 100.0 \\
\hline Types of Affiliation & f & $\%$ & $\mathbf{f}$ & $\%$ & & \\
\hline Franchising & 22 & 18.3 & 13 & 10.8 & 35 & 14.5 \\
\hline Management contract & 24 & 20 & 32 & 26.4 & 56 & 23.2 \\
\hline Independent hotels & 74 & 61.7 & 76 & 62.8 & 150 & 62.2 \\
\hline Total & 120 & 100 & 121 & 100 & 241 & 100.0 \\
\hline
\end{tabular}

Table 3. Exploratory Factor Analysis for Performance Measures

\begin{tabular}{llll}
\hline Measured Variables & $\begin{array}{l}\text { Factor 1 } \\
\text { Business } \\
\text { Performance }\end{array}$ & $\begin{array}{l}\text { Factor 2 } \\
\text { Operational } \\
\text { Performance }\end{array}$ & Cronbach's Alpha \\
\hline Factor Loadings & & & \\
Revenues & 0.848 & & 0.691 \\
Corporate Image & 0.818 & & \\
Market Share & 0.811 & & \\
Occupancy & 0.779 & 0.822 & \\
Customer Loyalty & & 0.722 & \\
Customer Satisfaction & & 0.721 & \\
Employee Satisfaction & & 0.583 & \\
Low Cost in Production & & 0.515 & \\
Profitability & 3,735 & 1,714 & \\
Eigenvalue & 41.497 & 19,042 & \\
Variance explained \% & & & \\
Cumulative variance \% & 0.723 & & \\
Kaiser-Meyer-Olkin (KMO) & 0.000 & & \\
$p$ & & & \\
\hline
\end{tabular}

Note: Principal component factor extraction method and varimax rotation with Kaiser normalization.

ned above as the basis for EFA. The EFA produced two latent factors which had been identified initially from the literature: operational performance and business performance (see Table 3). In looking at Table 3, one will see that the operational and business performance factors were merged under the same variables stated in the literature, except for the profitability variable, which was categorized into the factor of operational performance. Furthermore, both of the latent factor loadings are above 0.515 , and this indicates the factor loadings are statistically significant (Hair et al.,
2005). Furthermore, the cumulative variances explained $(60.53 \%)$ for the latent factors are satisfactory for the study (See Table 3).

\section{Testing Hypothesis}

After comparing the ISO 9001 certified resort hotels (120) and the non-certified ISO 9001 resort hotels (121) regarding their operational and business performances ( $t$-test), a statistically significant difference was observed only in the operational performance between the ISO 9001 certified resort hotels and the non- ISO 9001 certified resort hotels, which is 
Duman, F., O. Ozer, M. Koseoglu, M. Altin and F. Okumus (2019) / European Journal of Tourism Research 23, pp. 142-155

Table 4. T-test for performance measures: ISO 9001 vs Non-ISO 9001certified resort hotels $(N=241)$

\begin{tabular}{llllllll}
\hline $\begin{array}{l}\text { Performance } \\
\text { Factors }\end{array}$ & Groups & $\boldsymbol{N}$ & Mean & $\begin{array}{l}\text { Standard } \\
\text { Deviation }\end{array}$ & $\boldsymbol{t}$ & $\boldsymbol{d}$ & $\boldsymbol{p}$ \\
\hline $\begin{array}{l}\text { Business } \\
\text { Performance }\end{array}$ & $\begin{array}{l}\text { ISO 9001 } \\
\text { Certified Hotels }\end{array}$ & 120 & 4.3625 & 0.61992 & -0.171 & 229,696 & 0.864 \\
& $\begin{array}{l}\text { Non-ISO 9001 } \\
\text { Certified Hotels }\end{array}$ & 121 & 4.3471 & 0.76674 & & & \\
& $\begin{array}{l}\text { ISO } 9001 \\
\text { Certified Hotels }\end{array}$ & 120 & 3.8167 & 0.53927 & & & \\
$\begin{array}{l}\text { Operational } \\
\text { Performance }\end{array}$ & $\begin{array}{l}\text { Non-ISO 9001 } \\
\text { Certified Hotels }\end{array}$ & 121 & 4.2760 & 0.46279 & & & \\
& & & & & & \\
& & & & & & & \\
\hline
\end{tabular}

Note: Statistically significant difference at $p=0.000$

evident from the mean values of the ISO 9001 certified resort hotels (Mean=3.8167) and the non-ISO 9001 certified resort hotels (Mean=4.3471) (see Table 4 above). Specifically, it appears that the operational performance measure of the ISO 9001 certified resort hotels is statistically significant. However, it negatively affects operational performance of the ISO 9001 certified resort hotels when comparing the mean values.

\section{Discussion}

The findings present the profiles of the resort hotels and show that the ISO 9001 certified resort hotels are larger than the non-ISO 9001 certified resort hotels with the category of "401 and over rooms". This finding is consistent with the manufacturing samples studied by Psomas et al. (2011) and Psomas and Kafetzopoulos (2014). The other characteristics of the profiles, quality-starring and types of affiliation, produced what was expected from the resort hotels, meaning that five-star resort hotels and the type of franchising affiliation are higher than those that are non-ISO 9001 certified resort hotels. The authors suggest that the issues of being larger in size, higher in quality-starring, and franchising affiliation in service organizations, such as the resort hotels in this case, become more important in adopting the ISO 9001 quality certification for their service delivery consistency leading to increased customer satisfaction and loyalty.
Comparison of certified and non-certified resort hotels based upon the business and operational measures shows that neither sample of resort hotels produced any statistically significant differences in business performance comprising of revenues, corporate image, market share, and occupancy. The performance measures used show that the implementation of the ISO 9001 certification does not specifically result in a statistically significant and positive relationship with the business performance $(t=-0.171 ; p=0.864)$. Therefore, $\mathrm{H} 1$ is rejected.

The $t$-test showing the variation between the ISO 9001 certified and non-certified resort hotels on the operational performance as seen in Table 4 indicates a significant association with the hypothesized direction $(t=7,094 ; p=$ 0.000 ). However, this significant association with the operational performance is lower for the ISO 9001 certified resort hotels (Mean=3.8167) than the non-ISO 9001 certified resort hotels (Mean=4.3471). In summation, there is a statistically significant but negative association with the ISO 9001 quality certification. Therefore, $\mathrm{H} 2$ is partially accepted.

Comparing this study to the literature associated with the ISO 9001 certification and business performance shows a contradictory relationship. Contrary to what is typically expected for the positive contribution from the 
ISO 9001 quality certification in service organizations, this study did not produce a significant and positive association between the implementation of the ISO 9001 certification and business performance. Because, this finding was assumed that the sample hotels did not internalize ISO 9001 quality system into their organizations as they focused more upon solving the low occupancy rates and reduced room prices caused by the Russian crisis occurred in November 2016. Thus, the outcome of this study contradicts a number of the studies that produced significant and positive associations. However, it supports other studies that did not find any significant and positive relationship on business performance (Haversjo, 2000; Lima et al., 2000; Aarts and Vos, 2001; Dunu et al., 2002; Heras et al., 2002; Martinez-Costa and Martinez-Lorente, 2003; Dimara et al., 2004; Naveh and Marcus, 2005; Sampaio et al., 2011; Ilkay and Aslan, 2012; HerasSaizarbitoria et al., 2015; Ochieng et al., 2015; Kusumah and Fabianto (2016); Islam et al., 2016).

Similar to the present study, the relationship between the ISO 9001 quality certification and operational performance is supported by a number of studies (Feng et al., 2008; Jang and Lin, 2008; Wu and Chen, 2011; Al-Refaie et al., 2012; Psomas et al., 2012; Chatzoglou et al., 2015). However, it should be noted that this study resulted in a statistically significant variance, but a negative one. Overall, these findings suggest that the ISO 9001 certified resort hotels should have a clear objective when implementing a quality certification. Then, adopting and implementing the ISO 9001 quality certification should be internalized from the top to the bottom of any service organizations, such as the resort hotels. This would be supported by providing extensive staff training on implementation of the ISO 9001 quality standards (Brisco et al., 2005). In turn, the staff training should cover the skills needed to effectively and efficiently implement the quality initiatives in question, and the staff training should be a part of the medium to longterm strategy for the certified resort hotels.

\section{Conclusions}

The main finding of the study is that ISO 9001:2015 quality standards certification has 150 statistically significant but negative effect on the operational performance of resort hotels. To a certain extent, the negative relationship between ISO 9001 certification and operational performance for resort hotels is somewhat surprising, as ISO 9001 holistically focuses on the processes and continuous improvement to manage risks in advance in order to increase customer satisfaction and loyalty, employee satisfaction, and low cost in production. What is mainly understood from this finding is that adopting ISO 9001 quality certification in and of itself does not guarantee any improvement on the operational performance. Moreover, this study demonstrates no relationship between ISO 9001 quality certification and business performance (corporate image, market share, occupancy and revenues) in resort hotels. This is a notable finding that adopting ISO 9001 quality standards certification does not guarantee any improvements in the business performance of the resort hotels. However, ISO 9001 quality certification holistically focuses on the processes and continuous improvement leading to both customer satisfaction and low cost in production covering the whole operational system, which would then result in some positive contribution toward business performance (e.g. increase in occupancy and revenues). In short, one might conclude that the resort hotels should adopt ISO 9001:2015 quality system for more internal motivations (continuous improvements for customer and employee satisfaction leading to better service offerings and increase in profitability) rather than external motivations (i.e. marketing advantages).

\section{Managerial implications}

It is important to consider the fact that Turkish resort hotels operate under a distinct seasonal effect caused by international demand, which is high in the months of July and August, coupled with political situations with international markets (e.g. the Turkish-Russian conflict in 2015 and 2016). In addition, the study findings were obtained shortly after the aforementioned conflict ended in 2017. Even with resort hotels operating under the decreasing international demand in certain time periods, they should consider ISO 9001:2015 quality standards a dynamic quality management tool for performance improvement. Thus, the 
management of the resort hotels should incorporate quality management systems, and, more specifically, they should focus on ISO 9001 quality certification. By doing this, when harmful macro-environmental events occur in the international markets, the resort hotels would benefit from ISO 9001 quality standard procedures in order to improve their performance measures. The ISO 9001 quality system structure could be laid for the resort hotels to withstand the decrease in demand, survive, and be more competitive (Psomas and Kafetzopoulos, 2014).

Another implication for the resort hotel managers is the significant, but negative, relationship between ISO 9001 quality certification and operational performance. It is believed that when the ISO 9001 quality management system is well-established and implemented from the top down in the resort hotels, the significant but negative operational performance relationship of ISO 9001 quality certification would evolve into a positive relationship with operational performance. In turn, it would positively contribute to the business performance in resort hotels, as well. On the operational side, resort hotels should take ISO 9001:2015 quality system as the performance benchmark (Asrofah et al., 2010). Resort hotels as service-producing companies should be consistent with their offerings to customers in order to maintain customer satisfaction and loyalty as the main principle of their operations. In doing so, the resort hotels would survive and be competitive in today's competitive environment.

\section{Limitations and future research}

This study has some limitations. The sample only covered the four and five-star ISO 9001 and non-ISO 9001 certified resort hotels in Turkey. Thus, the SMEs (hotels) are not represented in this study. Further research is suggested in order to cover both the city and resort hotel samples of ISO 9001 certified and non-certified hotels in order to see differences in the operational and business performances. Second, we used firm performance with two components including operational performance and business performance. Future research should consider other performance measurement models such as Sainaghi (2010)' s model including qualitative clients' indicators, operational performance indicators, business or financial performance indicators, and organizational or institutional indicators. Finally, the effects of ISO 9001 on performance should be studied on a longitudinal basis as the Turkish tourism industry is affected by macroenvironmental issues (e.g. the recent RussianTurkish post crisis relations). A similar style of research could be carried out in a country facing similar macro-environmental pressure such as Egypt and Greece.

\section{References}

Aarts, F. M., \& Vos, E. (2001). The impact of ISO registration on New Zealand firms' performance: a financial perspective. The TQM Magazine, 13(3), 180-191.

Aba, E. K., \& Badar, M. A. (2013). A review of the impact of ISO 9000 and ISO 14000 certifications. Journal of Technology Studies, 39(1), 42-50.

Aba, E. K., Badar, M. A., \& Hayden, M. A. (2016). Impact of ISO 9001 certification on firms financial operating performance. International Journal of Quality \& Reliability Management, 33(1), 78-89.

Agus, A., \& Hajinoor, M. S. (2012). Lean production supply chain management as driver towards enhancing product quality and business performance: a case of manufacturing companies in Malaysia. International Journal of Quality \& Reliability Management, 29(1), 92-121.

Ahire, S. L., \& O'Shaughnessy, K. C. (1998). The role of top management commitment in quality management: an empirical analysis of the auto parts industry. International Journal of Quality Science, 3(1), 5-37.

Alic, M., \& Rusjan, B. (2010). Contribution of the ISO 9001 internal audit to business performance, International Journal of Quality \& Reliability Management, 27(8), 916-937.

Al-Rawahi, A. M. S., \& Bashir, H. A. (2011). On the implementation of ISO 9001:2000: a comparative investigation, The TQM Journal, 23(6), 673-687.

Al-Refaie, A., Ghnaimat, O., \& Li, M. H. (2012). Effects of ISO 9001 certification and KAAE on performance of Jordanian firms. 
Does Quality Standards Certification Truly Matter on Operational and Business Performances of Firms? Evidence from Resort Hotels.

Jordan Journal of Mechanical \& Industrial Engineering, 6(1), 45-53.

Altin, M., Koseoglu, M. A., Yu, X., \& Riasi, A. (2018). Performance measurement and management research in the hospitality and tourism industry. International Journal of Contemporary Hospitality Management, 30(2), 1172-1189.

Alonso-Almeida, M. M, \& Rodríguez-Antón, J. M. (2011). Organisational behaviour and strategies in the adoption of certified management systems: an analysis of the Spanish hotel industry. Journal of Cleaner Production, 19(13), 1455-1463.

Asrofah, T., Zailani, S., \& Fernando, Y. (2010). Best practices for the effectiveness of benchmarking in the Indonesian manufacturing companies. Benchmarking: An International Journal, 17(1), 115-143.

Bayati, A., \& Taghavi, A. (2007). The impacts of acquiring ISO 9000 certification on the performance of SMEs in Tehran, The TQM Magazine, 19(2), 140-149.

Beirao, G., \& Cabral, S. (2002). The reaction of the Portuguese stock market to ISO 9000 certification. Total Quality Management, 13(4), 465-474.

Briscoe, J. A., Fawcett, S. E., \& Todd, R. H. (2005). The implementation and impact of ISO 9000 among small manufacturing enterprises. Journal of Small Business Management, 43(3), 309-330.

Chatzoglou, P., Chatzoudes, D., \& Kipraios, N. (2015). The impact of ISO 9000 certification on firms' financial performance. International Journal of Operations \& Production Management, 35(1), 145-174.

Chow-Chua, C., Goh, M., \& Wan, T. B. (2003). Does ISO 9000 certification improve business performance? International Journal of Quality \& Reliability Management, 20(8), 936-953.

Claver, E., Tarí, J. J., \& Pereira, J. (2006). Does quality impact on hotel performance? International Journal of Contemporary Hospitality Management, 18(4), 350-358.

Cooper, D. R., \& Schindler, P. S. (1998). Business Research Methods, 6. Edition, New York: McGraw-Hill.

Dimara, E., Skuras, D., \& Tsekouras, K. (2004). Strategic orientation and financial performance of firms implementing ISO 9000. International Journal of Quality \& Reliability Management, 21(1), 72-89.

Dow, D., Samson, D., \& Ford, S. (1999). Exploding the myth: do all quality management practices contribute to superior quality performance? Production and Operations Management, 8(1), 1-27.

Dunu, E. S., \& Ayokanmbi, M. F. (2008). The impact of ISO 9000 certification on the financial performance of organizations. Journal of Global Business Issues, 2(2), 135-144.

Feng, J., Prajogo, D. I., Tan, K. C., \& Sohal, A. S. (2006). The impact of TQM practices on performance: A comparative study between Australian and Singaporean organizations. European Journal of Innovation Management, 9(3), 269-278.

Feng, M., Terziovski, M., \& Samson D. (2008). Relationship of ISO 9001:2000 quality system certification with operational and business performance: a survey in Australia and New Zealand-based manufacturing and service companies. Journal of Manufacturing Technology Management, 19(1), 22-37.

Flynn, B. B., Schroeder, R. G., \& Sakakibara, S. (1995). The impact of quality management practices on performance and competitive advantage. Decision Sciences, 26(5), 659-691.

Gonzalez-Benito, J. (2005). A study of the effect of manufacturing proactivity on business performance. International Journal of Operations \& Production Management, 25(3), 222-241.

Hair, J. F. J., Black, W., Babin, B. J., \& Tatham, R. L. (2005). Multivariate Data Analysis, New Jersey: Prentice Hall.

Haversjo, T. (2000). The financial effects of ISO 9000 registration for Danish companies. Managerial Auditing Journal, 15(1/2), 47-52.

Heras, I., Dick, G. P. M., \& Casadesus, M. (2002). ISO 9000 registration's impact on sales and profitability: a longitudinal analysis of performance before and after accreditation. International Journal of Quality \& Reliability Management, 19(6), 774-791.

Heras-Saizarbitoria, I., Arana, G., \& Boiral, O. (2015). Do ISO 9001-certified hotels get a 
higher customer rating than non-certified ones? International Journal of Hospitality Management, 51, 138-146.

Ilkay, M. S., \& Aslan, E. (2012). The effect of the ISO 9001 quality management system on the performance of SMEs. International Journal of Quality \& Reliability Management, 29(7), 753-778.

Islam, M., \& Karim, A. (2011). Manufacturing practices and performance. Comparison among small-medium and large industries. International Journal of Quality \& Reliability Management, 28(1), 43-61.

Islam, M. M., Habes, E., Karim, A., \& Syed Agil, S. O. (2016). Quality certification and company performance - the newly developed country experience. Journal of Business Economics \& Management, 17(4), 628-644.

ISO (2017), The ISO Survey of Certifications, ISO, Geneva.

Jang, W. H., \& Lin, C. I. (2008). An integrated framework for ISO 9000 motivation, depth of ISO 9000 implementation and firm performance: the case of Taiwan. Journal of Manufacturing Technology Management, 19(2), 194-216.

Kaynak, H. (2003). The relationship between total quality management practices and their effects on firm performance. Journal of Operations Management, 21(4), 405435.

Kusumah, L. H., \& Fabianto, Y. S. (2016). The differences in the financial performance of manufacturing companies in Indonesia before and after ISO 9000 implementation. Total Quality Management \& Business Excellence, 29(7-8), 941-957.

Lakhal, L. (2009). Impact of quality on competitive advantage and organizational performance. The Journal of the Operational Research Society, 60(5), 637-645.

Lima, M. A. M., Resende, M., \& Hasenclever, L. (2000). Quality certification and performance of Brazilian firms: an empirical study. International Journal of Production Economics, 66(2), 143-147.

Lloyd's Register Quality Assurance Limited (1995), The Effects of ISO 9000 on Business Performance, LRQA Publication, London.
Lo, C. K.Y., Pagell, M., Fan, D., Wiengarten, F., \& Yeung, A. C. L. (2014). OHSAS 18001 certification and operating performance: the role of complexity and coupling. Journal of Operation Management, 32(5), 268-280.

Martínez-Costa, M. and Martínez-Lorente, A.R. (2003), "Effects of ISO 9000 certification on firms' performance: a vision from the market", Total Quality Management and Business Excellence, 14(10), 1179-1191.

Minazzi, R., 2006. Quality certification in services: "The case of hospitality industry". Management-"casopis za teoriju i praksu menad'zmenta, 11(42), 33-38.

Mokhtar, M. Z., \& Muda, M. S. (2012). Comparative study on performance measures and attributes between ISO and non-ISO certification companies. International Journal of Business and Management, 7(3), 185-193.

Naser, K., Karbhari, Y., \& Mokhtar, M. Z. (2004). Impact of ISO 9000 registration on company performance: evidence from Malaysia. Managerial Auditing Journal, 19(4), 509-516.

Nava Carballido, V. M. \& Rivas-Tovar, L. A. (2008). Desempeño de las organizaciones mexicanas certificadas en la norma ISO 9001:2000. Estudios Gerenciales, 24 (108), 107-128.

Naveh, E., \& Marcus, A. (2005). Achieving competetive advantage through implementing a replicable management standard: installing and using ISO 9000. Journal of Operations Management, 24(1), 1-26.

Nicolau, J. L., \& Sellers, R. (2002). The stock market's reaction to quality certification: Empirical evidence from Spain. European Journal of Operational Research, 142(3), 632-641.

Nield, K., \& Kozak, M. (1999). Quality certification in the hospitality industry. Cornell Hotel \& Restaurant Administration Quarterly, 40(2), 40-52.

Ochieng, J., Muturi, D., \& Njihia, S. N. (2015). The impact of ISO 9001 implementation on organizational performance in Kenya. The TQM Journal, 27(6), 761-771.

Pallant, J. (2007), SPSS Survival Manual: A Step by Step Guide to Data Analysis 
Does Quality Standards Certification Truly Matter on Operational and Business Performances of Firms? Evidence from Resort Hotels.

Using SPSS for Windows, 3rd Edition, US: Data/Computers-Technology

Parthiban, P., \& Goh, M. (2011). An integrated model for performance management of manufacturing units. Benchmarking: An International Journal, 18(2), 261-281.

Piero-Signes, A., Segarra-Ona, M. D. V., Verma, R., Mondejar-Jimenez, J., \& Vargas-Vargas, M. (2014). The impact of environmental ratings on hotel guest ratings. Cornell Hospitality Quarterly, 55(1), 40-51.

Powell, T. C. (1995). Total quality management as competitive advantage: a review and empirical study. Strategic Management Journal, 16, 15-37.

Psomas, E., \& Kafetzopoulos, D. (2014). Performance measures of ISO 9001 certified and non-certified manufacturing companies, Benchmarking: International Journal, 21(5), 756-774.

Psomas, E., Fotopoulos,C., \& Kafetzopoulos, D. (2011). Core process management practices, quality tools and quality improvement in ISO 9001 certified manufacturing companies. Business Process Management Journal, 17(3), 437460.

Psomas, E., Kafetzopoulos, D., \& Fotopoulos, C. (2012). Developing and validating a measurement instrument of ISO effectiveness in food manufacturing SMEs. Journal of Manufacturing Technology Management, 24(1), 52-77.

Rahman, S., \& Bullock, P. (2005). Soft TQM, hard TQM, and organizational performance relationships: an empirical investigation. Omega, 33, 73-83.

Rao, S. S., Ragu-Nathan, T. S., \& Solis, L. E. (1997). Does ISO 9000 have an effect on quality management practices? An international empirical study. Total Quality Management, 8(6), 335-346.

Rubio-Andrada, L., Del Mar Alonso-Almeida, M., \& Rodríguez-Antón, J. M. (2011). Motivations and impacts in the firm and stakeholders of quality certification: Evidence from small-and medium-sized service enterprises. Total Quality Management \& Business Excellence, 22(8), 833-852.

Sainaghi, R. (2010). Hotel performance: state of the art. International Journal of
Contemporary Hospitality Management, 22(7), 920-952.

Sainaghi, R., Phillips, P., \& Corti, V. (2013). Measuring hotel performance: Using a balanced scorecard perspectives' approach. International Journal of Hospitality Management, 34(1), 150-159.

Sainaghi, R., Phillips, P., Baggio, R., \& Mauri, A. (2018). Cross-citation and authorship analysis of hotel performance studies. International Journal of Hospitality Management, 73, 75-84.

Sainaghi, R., Köseoglu, M. A., d'Angella, F., \& Tehheh, I. L. (2019). Foundations of hospitality performance measurement research: A co-citation approach. International Journal of Hospitality Management, 79, 21-40.

Sampaio, P., Saraiva, P., \& Rodrigues, A. G. (2011). ISO 9001 certification forecasting models, International Journal of Quality \& Reliability Management, 28(1), 5-26.

Samson, D., \& Terziovski, M. (1999). The relationship between total quality management practices and operational performance. Journal of Operations Management, 17(4), 393-409.

Skrinjar, R., Vuksic, V. B., \& Stemberger, M. I. (2008). The impact of business process orientation on financial and non-financial performance. Business Process Management Journal, 14(5), 738-754.

Su, Q., Li, Z., Zhang, S.X., Liu, Y.Y., \& Dang, J. $X$. (2008). The impacts of quality management practices on business performance. An empirical investigation from China. International Journal of Quality \& Reliability Management, 25(8), 809-823.

Tabachnick, B. ve Fidell, L. (2007), Using Multivariate Statistics, 5. Edition, USA: Pearson Education.

Tarí, J. J., Claver-Cortés, E., Pereira-Moliner, J., \& Molina Azorín, J. F. (2009). Is it worthwhile to be a quality certified hotel? Evidence from Spain. International Journal of Quality \& Reliability Management, 26(9), 850-864.

Tarí, J. J., Heras-Saizarbitoria, I., \& Dick, G. (2014). Internal and external drivers for quality certification in the service industry: Do they have different impacts on 
success? Service Business, 8(2), 337354.

Tarí, J. J., Claver-Cortés, E., Pereira-Moliner, J., \& Molina-Azorín, J. F. (2010). Levels of quality and environmental management in the hotel industry: their joint influence on firm performance. International Journal of Hospitality Management, 29(3), 500-510.

Trigueros Pina, J. A., \& Sansalvador Sells, M. E. (2008). Management and measurement of quality in ISO 9000 organisations: an empirical study in Spain. Total Quality Management \& Business Excellence, 19(5), 481-492.

Tsekouras, K., Dimara, E., \& Skuras, D. (2002). Adoption of a quality assurance scheme and its effect on firm performance: a study of Greek firms implementing ISO 9000. Total Quality Management, 13(6), 827841.

Turkish Ministry of Culture and Tourism (2016), www.kultur.gov.tr/TR.96270/turizm-verile ri.html.
Wayhan, V. B., Kirche, E. T., \& Khumawala, M. (2002). ISO 9000 certification: the financial performance implications. Total Quality Management, 13(2), 217231.

White, G. R. T., Samson, P., Rowland-Jones, R., \& Thomas, A. J. (2009). The implementation of a quality management system in the not-for-profit sector. The TQM Magazine, 21(3), 273-283.

Wu, S. I., \& Chen, J. H. (2011). Comparison between manufacturing companies that are ISO certified and those that are not certified using performance measurement model. Total Quality Management \& Business Excellence, 22(8), 869-890.

Zeng, S. X., Tian, P., \& Tam, C. M. (2007). Overcoming barriers to sustainable implementation of the ISO 9001 system. Managing Auditing Journal, 22(3), 244254. 